\title{
POSSIBLE CHANGES IN TRANSPORT CONCEPTION OF INTERNATIONAL AND LONG-DISTANCE RAILWAY CONNECTIONS RELATING THE CONSTRUCTION OF NEW HIGH-SPEED RAILWAY LINES IN THE CZECH REPUBLIC
}

\author{
Pavel Purkart*, David Vodák, Tomáš Javořík, Martin Jacura \\ Czech Technical University in Prague, Faculty of Transportation Sciences, Department of Transportation \\ Systems, Horská 3, 12803 Prague 2, Czech Republic \\ * corresponding author: purkapav@fd.cvut.cz
}

\begin{abstract}
The aim of this article is to deal with the issue of high-speed railway lines (HSL) in the Czech Republic in response to the Fast connections conception ("Rychlá spojení" in Czech, abbreviation "RS"). Currently the RS1, RS2 and RS4 projects are the most watched during the preparation of the HSL network construction. The authors would like to focus on this issue from the wider point of view and to assess possible impact on the current lines of long-distance trains, the location of graphical timetable nodes and the way of the transport service on the area of the state.
\end{abstract}

Keywords: High-speed railway lines, Czech Republic, graphical timetable, international transportation, long-distance transportation, travel time, transport junction.

\section{INTRODUCTION}

Currently there is an ongoing development of Czech HSL network in response to the Fast connections conception. There are not any HSL in the Czech Republic now. This situation is not, with respect to the sustainable development and the situation in the neighbouring states of the former Western Europe, acceptable, but this topic is being revived and preparation of selected RS sections is accelerating.

The Construction of New High-speed Railway Lines (HSL) in the Czech Republic is currently an actual topic. The Fast connections ("Rychlá spojení" in Czech, abbreviation "RS") system has defined following main directions of the fast railway network [1]:

- RS1 Praha (Prague) - Brno - Ostrava - [Poland],

- RS2 Brno - [Slovakia/Austria],

- RS3 Praha - Plzeň (Pilsen) - [Germany] (western direction - München),

- RS4 Praha - [Germany] (northern direction - Dresden) with possible branch (Most - Chomutov, Žatec, Louny),

- RS5 Praha - Hradec Králové/Liberec - [Poland].

We can see the Fast Connections conception in Figure 1 .

Currently the RS1, RS2 and RS4 projects are the most watched during the preparation of the HSL network construction. The aim of this article is to focus on this issue from the wider point of view and to assess possible impact on the current lines of long-distance trains, the location of graphical timetable nodes and the way of the transport service on the area of the state. According to the Správa železnic (the main Czech railway infrastructure manager), first sections of the RS network should be put into operation by the year 2028, which makes this issue very actual.

\section{Goals of the Article}

This article is mainly focused on the impacts of the RS network and changes in transport planning, especially:

- Evaluation of RS conception,

- possible line routing in the international transportation,

- discussing possible impacts in national long-distance transportation.

\section{Solution of the Issue}

\subsection{Evaluation of RS Conception}

According to the research team, the basic design of the $\mathrm{RS}$ network is consistent. RS conception considers the most important national and international transport flows. Decrease of the travel times to Praha (Prague) is shown in the Figure 2.

$\mathrm{t}$ is logical to solve RS1, RS2 and RS4 branches in the first place, but we should not omit RS3 branch, because it connects the area of Plzeň and southern Germany. This connection represents a strong transport relation, but currently it is not certain what parameters and routing should this route have between Plzeň and Germany. It is alarming, considering that more than thirty years have passed since the fall of the iron curtain. The defined RS5 direction is also suitable for reflection. RS5 route could be extended to the south Bohemia (with connection to Austria), because this area is currently not fully connected to the RS network.

Goals of RS network construction of railway transportation development are essential: 


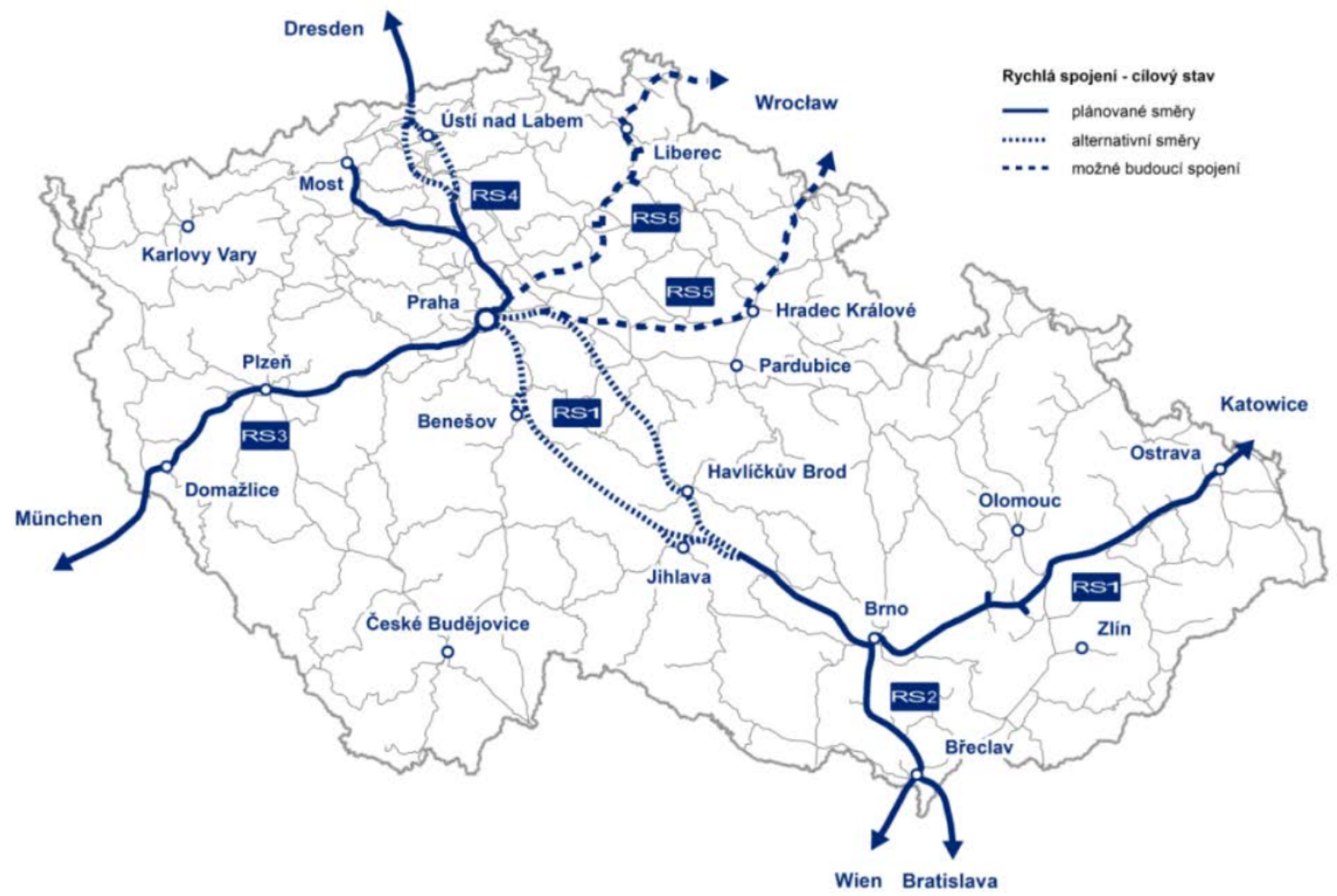

FIGURE 1. RS network (continuous lines represent planned RS connections, dashed lines represent possible future connections, dotted lines represent alternatives), source: [2].

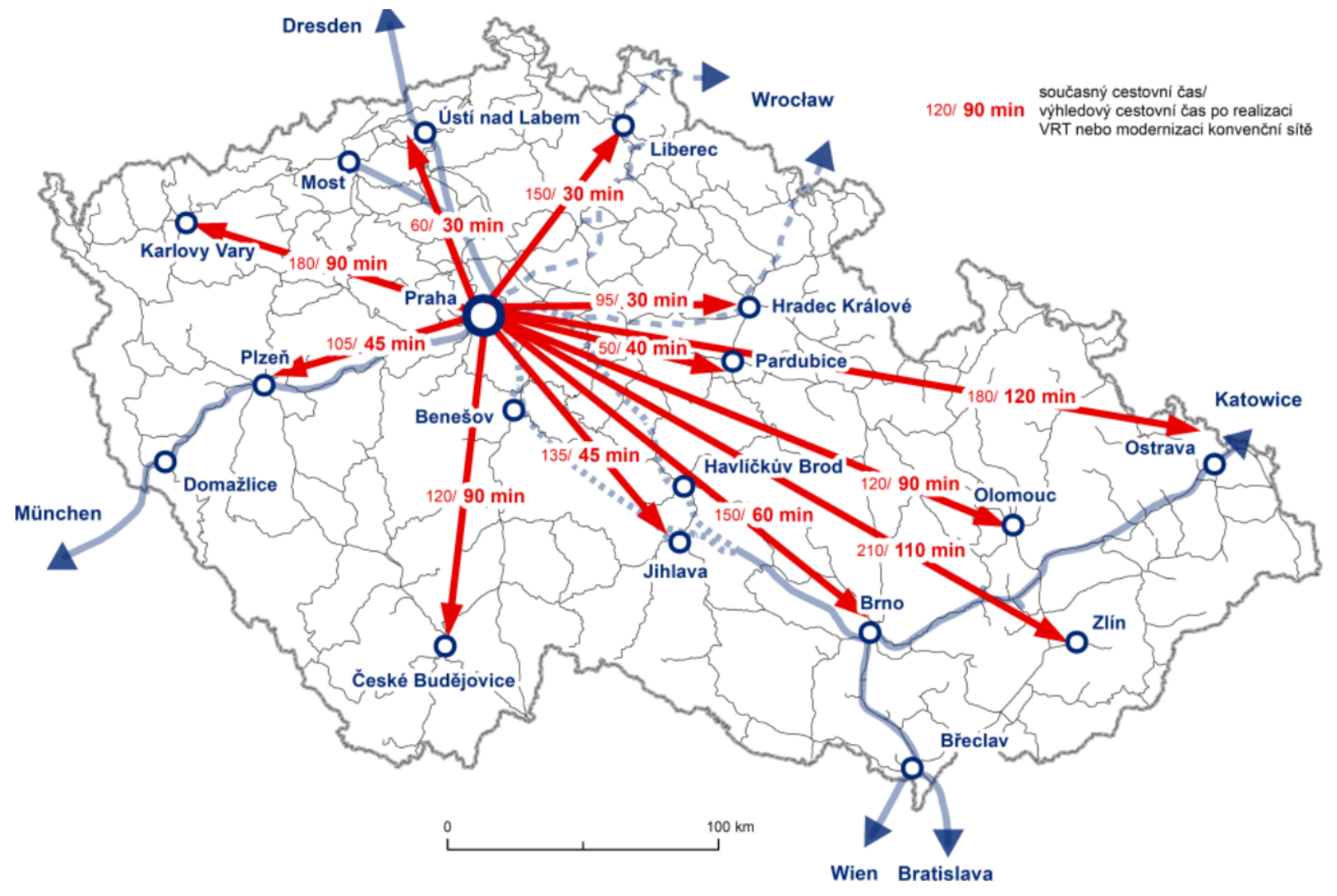

FiguRE 2. Estimated travel times decrease after the RS network construction, compared to the situation in 2018 $(120 / 90 \mathrm{~min}=$ travel time in $2018 /$ prospective travel time after the HSL construction or conventional network modernization), source: [2]. 
- Increasing the importance of the Czech railway network for international transport,

- cutting the travel times between Praha and all regional capitals to 120 minutes or lower, to achieve this goal RS lines should be used both by high-speed and conventional trains,

- lowering traffic density on the overloaded section of railway network, so suburban and freight trains could use it.

Another important issue is the organization of railway traffic on new RS lines. Currently railway traffic is ordinarily organised according to the graphical timetable. This approach should be also applied on the new RS lines.

Principles of graphical timetable can be mathematically described by using two simple equations. The edge equation has the following Formula (1):

$$
t_{H}=n \cdot \frac{1}{2} t_{T}
$$

The Formula (2) is the circumferential equation:

$$
\sum t_{H}=n * t_{T}
$$

Above-stated variables mean:

- $t_{T}$ - tact time (service interval),

- $t_{H}$ - time weight of the edge between two tact nodes,

- $n$ - natural number (depends on individual situation) [3].

Both these equations can be easily explained in order to understand their real meaning.

The edge equation shows that vehicles from one line are passing each other after one-half of the tact time. In case of public transport line with tact time 60 minutes the vehicles of opposite directions pass each other every 30 minutes. Vehicles pass on the route at the place where the symmetry axis is. On single-track railway line, we have to build a passing point. On the lines with two or more tracks, vehicles can pass each other on the route. We can assume that the perfect travel time between two important transport nodes equals one-half of the tact time.

Circumferential equation is related to the term circle (close sequence of edges and nodes) from the graph theory. It says that total count of system travel time on the all edges should ideally equal a multiple of natural number of the tact time. In such case, strong relations between the lines in the nodes are ensured.

\subsection{Possible Line Routing in LONG-DISTANCE INTERNATIONAL TRANSPORTATION}

Construction of the RS1 and RS2 sections is crucial for national transport relationships, because it can significantly help to overloaded sections of first and third transit railway corridor. We can also assume, that lines on HSL will be integrated to the international connections - HSL are used both by national and international lines.

There are already international lines on the Czech railway network. Those lines have high quality vehicles, but their travel speed does not exceed $100 \mathrm{~km} / \mathrm{h}$, which is not sustainable in the context of today's "distance reduction". Selected lines are even bypassing Czech Republic, because longer route outside of the Czech Republic offers better travel time. Construction of the RS network should improve this situation and increase the importance of the Czech railway network for international transportation.

Possible conception of international lines is shown on the network graphics in the Figure 3

Following lines of international trains can create the core of transport services in the RS network scenario:

- Wien - Brno - Praha - Dresden - Berlin. This line should ideally reach systemic travel time four hours along the entire route, which means one hour between each city. This should provide optimal travel time between individual nodes. Current travel time is eight hours - construction of RS1 and RS2 can cut down the travel times by one half. It is alarming, that current fastest connection Wien Berlin is not routed through the area of the Czech Republic, but only through Germany and Austria. Travel time of connection routed through the area of the Czech Republic is slightly longer - this clearly proves unsatisfactory condition of our railway network for international transportation,

- Warszawa - Ostrava - Brno - Praha - Plzeň München. This line also contains section of the RS3. Current travel time of long distance train lines is eleven hours, but these lines are also not routed through the area of the Czech Republic. At the same time, there is not an intention to build the RS3 in the parameters of HSL. Reaching the travel time under eight hours can be considered as a success. We should reach following travel times for the optimal locations of graphical timetable nodes: Warszawa - Ostrava three hours, Ostrava - Praha two hours and Praha - München 3 hours.

The above-stated network is basic and it consists of two lines with international meaning. For its addition and full use of the RS network, we can also assume following lines:

- Košice - Ostrava - Brno - Praha - Plzeň - Nürnberg, similar to line Warszawa - München in east-west direction. It connects east part of Slovakia, Czech Republic and Germany. Travel time through Czech Republic should not exceed 4 hours. Travel time on the area of other states should not be higher in order to keep the international line attractive for passengers, 

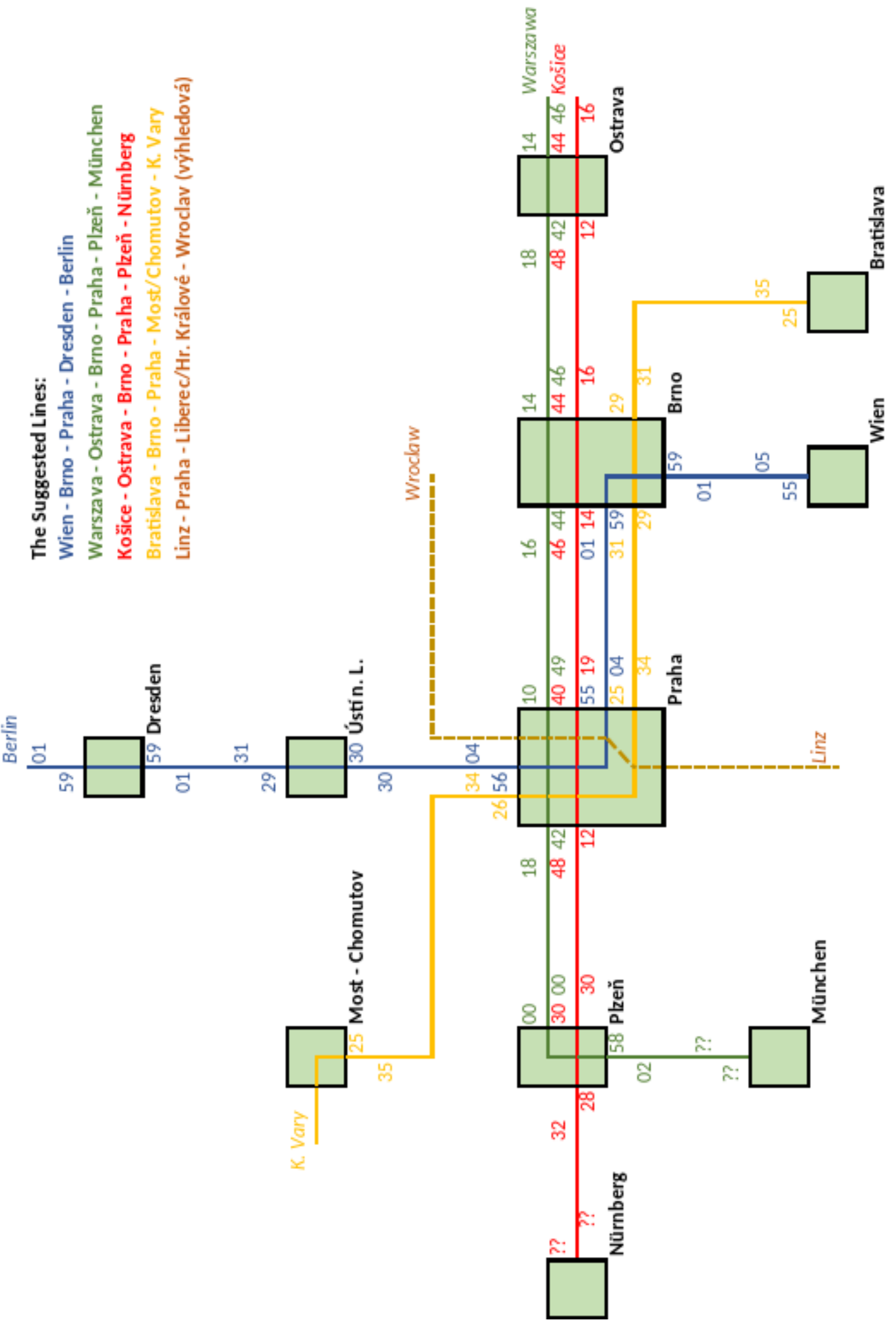

FiguRE 3. Network graphics of possible line routing in the international transportation. 
- Budapest - Bratislava - Brno - Praha Most/Chomutov - Karlovy Vary is a line, which connects the capitals of the Czech and Slovak Republic. It does not have to end in the Praha, but it can go to the area of Most (on the designed RS line) and further to the Karlovy Vary (on the conventional line),

- It is appropriate to mention the line Linz - České Budějovice - Praha - Warszawa in case of construction of the RS5.

International lines can create following peak intervals on the area of the Czech Republic (assuming that they will be operated with the 60 minutes' interval):

- interval 15 minutes Praha - Brno,

- interval 30 minutes Praha - Ostrava,

- interval 30 minutes Praha - Plzeň.

With these operational parameters and sufficient length of the trains, the international lines can serve the national relations without any additional national lines. For example, there is 15 minutes' interval on the relation Praha - Brno, which is close to the parallel graphical timetable of subway.

It is apparent that Praha will become an important railway node at an international level. Its significance could be very close to nodes such as Wien and Berlin.

\subsection{Possible Impacts on the National LOnG-Distance Transportation}

The above-mentioned international lines are going to bring significant travel times reduction also in the most important national lines. There will be also additional lines with lower importance. International lines are going to affect national transportation, because many passengers, who are using current national lines, are going to use new connections routed on RS/HSL. Construction of RS/HSL is going to bring key changes in the current line routing. We can shortly mention following impacts on current lines:

- line Ex1 Praha - Ostrava is going to lose its importance; important cities (Pardubice and Olomouc) are going to remain outside of the RS, therefore it will be necessary to solve their connection. The RS network is probably not going to be important for Pardubice, but we have to evaluate it for Olomouc,

- line Ex3 Praha - Brno is going to lose its importance similar to line Ex1 Praha - Ostrava,

- ine Ex5 Praha - Dresden - Berlin also loses necessity for connection of those cities, in Ústí nad Labem case it depends whether it is on RS route or not (we can consider stopping of the line Wien - Berlin). We definitely have to change the conception of the line R15 Praha - Ústí nad Labem - Most - Karlovy Vary - Cheb. If a new line with HSL parameters is built, including a branch to the Most area, this line, in its current form, loses its importance for connection with Praha. It is purposeful to divide this line into three lines, for example:

$\triangleright$ Praha - Most - Chomutov - Karlovy Vary - Cheb with systemic travel time Praha - Karlovy Vary in phase one maximally two hours, then maximally one and half hour (for fast connection Praha Karlovy Vary),

$\triangleright$ Praha - Ústí nad Labem - Teplice - Litvínov,

$\triangleright$ Děčín - Ústí nad Labem - Teplice - Bílina - Most

- Chomutov.

- line Ex6 Praha - Plzeň is primarily going to be routed on $\mathrm{RS}$ line, if there is not any segment of conventional line remained. We have to question the importance of the line R16 Praha - Plzeň Klatovy, which is partly regional, but, thanks to the strong transport connection between Klatovy area and Praha, it can be divided into two lines in Plzeň - selected trains from Klatovy area may be routed on RS line from Plzeň.

\section{Conclusion}

We can expect smaller or bigger impacts from building the RS network on almost every line, however our main goal should be total passenger increase in public transportation, balanced use of railway network, reduction of travel times between the cities and reduction of environmental damages from the individual car transportation. It is necessary to point out, that high-speed railway transportation has to be attractive and affordable. Otherwise our goals cannot be reached.

\section{ACKNOWLEDGEMENTS}

All the facts presented in this article are based on the results of the research on the CTU Faculty of Transportation Sciences, Department of Transport Systems. This research was supported by the Grant Agency of the Czech Technical University in Praha, grant No. SGS18/150/OHK2/2T/16 Railway track parameters for transportation service optimization and No. SGS20/138/OHK2/2T/16 Design and optimal use of railway infrastructure parameters.

\section{REFERENCES}

[1] Vysokorychlostní tratě v ČR. [online], Praha: Správa železnic, 2020 [cit. 2020-02-22]. Dostupné z: https://www.szdc.cz/vrt/

[2] M. Švehlík, M. Pinkava, P. Provazník. Postup přípravy VRT v ČR. Vědeckotechnický sborník ČD. 2018, 25(46), 16. ISSN ISSN 1214-9047.

[3] K. Baudyš. Časové prvky JŘ. Systémové jízdní doby: Technologie železnižní dopravy. Praha, 2014. 